\title{
MEMBANGUN SISTEM INFORMASI MANAJEMEN PADA PT. BUNGA MEKAR INDUSTRI
}

\author{
Ali Farhan \\ STIE Mahardhika Surabaya \\ Ali.farhan@stiemahardhika.ac.id
}

\begin{abstract}
This study based on action research aims to formulate an effective work policy for PT Bunga Mekar Industri. Action research is an attempt to determine the performance of a process to be more effective (Farhan, 2017). PT Bunga Mekar Industri as a national pellet company in Jember found that the company did not have sufficient information for analysis, the results of this study were; 1) Making document of goods receipt, cash in, goods out, cash out; 2) make procedures for all Company activities, including finance, inventory, procurement, and production; 3) making production policies and calculating production costs to be able to present productivity reports to management.

Keywords; Action research; management; system; productivity
\end{abstract}

\section{Latar Belakang}

Sistem informasi manajemen memiliki sasaran implementasi strategi. Dalam menyusun sistem informasi manajemen, manajemen puncak memilih serangkaian metode yang menunjukkan strategi perusahaan. Metode-metode ini dapat dilihat sebagai faktor kesuksesan saat ini dan masa depan. Sistem informasi manajemen secara ringkas merupakan mekanisme perbaikan lingkungan organisasi agar berhasil dalam menerapkan strategi perusahaan. PT Bunga Mekar Industri merupakan perusahaan yang bergerak di bidang produksi pellet kayu uang ditujukan untuk kebutuhan baik dalam maupun luar negeri. Dengan bahan baku utama limbah kayu dan pasar yang sensitif terhadap isu mata uang juga isu lingkungan, Perusahaan membutuhkan serangkaian langkah strategis untuk dapat bertahan di dalam industrinya.

Pengelolaan kas, investasi alat produksi, pengadaan bahan baku, juga manajemen sumber daya manusia merupakan beberapa isu manajemen yang harus dikelola oleh Perusahaan yang beroperasi sejak 2019 ini. Ketiadaan sistem informasi manajemen menjadikan Perusahaan tidak memiliki pedoman yang jelas dalam menjalankan bisnisnya. Oleh karenanya penelitian ini dilakukan, yaitu guna mengimplementasikan serangkaian prosedur kerja yang memberikan informasi manajerial yang memadai bagi Perusahaan, supaya manajemen puncak memiliki informasi yang cukup untuk mengambil keputusan-keputusan strategis terkait kinerja Perusahaan. Berbasis pada situasi operasional Perusahaan dan kebutuhan pada Perusahaan di masa datang, implementasi sistem informasi manajemen dalam 
penelitian ini menggunakan pendekatan action research yang melibatkan partisipasi penuh peneliti dan subjek penelitian, hal ini sejalan dengan Kristianto et al (2015) dan Voronkova (2017) yang mengharuskan impelementasi sistem berwawasan strategis dan aktual.

\section{Metodologi Penelitian}

\section{a. Data Penelitian}

Data penelitian pada artikel ini adalah data primer, yaitu data yang langsung diperoleh dari sumber penelitian. Data tersebut berupa catatan wawancara dengan narasumber dan dokumen-dokumen transaksi.

\section{b. Jenis Penelitian}

Penelitian ini adalah penelitian kualitatif, yaitu penelitian yang berfokus pada analisis data yang sifatnya kualitas, berupa; sistem kerja, arus informasi, dan hasil diskusi dengan narasumber. Adapun pendekatan yang dipakai dalam memahami persoalan yang diangkat adalah studi kasus dengan metodologi penelitian berupa action research.

\section{c. Action Research}

Action research merupakan sebuah pendekatan penelitian yang bekerja layaknya sebuah siklus yang secara berlanjut memproduksi cara pandang baru, mengkonversi sudut pandang itu untuk menjadi sebuah aksi, lalu menganalisa hasil dari aktivitas tersebut (Kong, 2017; Wagemans dan Witschge, 2019). Korb dan Wagner (2016) dan Coghlan dan Brannick (2005) menjelaskan bahwa Action research adalah sebuah pendekatan riset yang berfokus pada pemahaman terhadap masalah dan menciptakan solusi praktis untuk permasalahan tersebut. Greenwood et al. (2003) dan Tripp (2005) mendefiniskannya sebagai suatu eksperimen sosial dengan memperkenalkan cara kerja evolusioner dan memonitor efek-efeknya. Action research merupakan sebuah usaha untuk menentukan atau meningkatkan kinerja sebuah proses agar lebih efektif (Farhan, 2017), dengan demikian maka dalam relasinya dengan penelitian ini action research merupakan sebuah cara yang digunakan untuk merekonstruksi system kerja yang pada PT Bunga Mekar Industri, supaya mendapatkan infromasi manajerial yang memadai untuk tata kelola Perusahaan yang strategis.

Pada setiap metodologi selalu mempunyai tahapan spesifik untuk dilakukan, Tripp (2005) menjelaskan setidaknya ada lima tahapan, hal yang sama juga dkemukakan oleh Huda (2013) sebagai berikut:

1. Mengidentifkasi masalah-masalah pokok yang ada sebagai dasar bagi organisasi untuk melakukan perubahan ke arah yang lebih baik. 
2. Membuat rencana tindakan (action planning), Peneliti dan partisipan memahami masalah yang ditemukan kemudian menyusun rencana tindakan yang tepat untuk menyelesaikan masalah yang ada.

3. Melakukan tindakan (action taking), Peneliti dan partisipan bersama-sama mengimplementasikan rencana tindakan dengan harapan dapat menyelesaikan masalah.

4. Melakukan evaluasi (evaluating), setelah masa implementasi (action taking) dianggap cukup kemudian peneliti bersama partisipan melaksanakan evaluasi hasil dari implementasi.

5. Pembelajaran (learning), Tahap ini merupakan bagian akhir siklus yang telah dilalui dengan melaksanakan review tahap-pertahap yang telah berakhir kemudian penelitian ini dapat berakhir. Demikian merupakan serangkaian tahapan yang dirumuskan oleh Huda (2013) untuk melakukan action research.

\section{Pembahasan}

3. 1. Menemukan Masalah

a. Tidak ada pencatatan dan pengelolaan data yang memadai

Perusahaan tidak memiliki catatan keuangan yang pasti dan terintegrasi dengan bisnis Perusahaan, hal ini disampaikan oleh Bapak Vanji selaku direktur

"Iya mas, kalau catatan keluar masuk kas sih ada, cuman ya itu kami ini tidak bisa membuat Laporan Keuangannya, jadi ya kami ini nggak tahu apakah kami ini rugi atau untung."

"Dokumen kaya nota-nota gitu sih kami lengkap mas, ya tapi sekedar kami rekap aja. Nah komisaris ini yang punya saham butuh laporan keuangan. Pengen tahu kondisinya untung apa rugi, sementara ini yang kami punya cuman rekap ini saja."

"Kami hanya punya kertas kerja Produksi, mas. Isinya ya jumlah pemakaian bahan baku, jumlah oli dan solar terpakai, dan hasil produksi harian. Sama siapa saja pekerja yang hadir hari itu."

b. Tidak ada prosedur dan sistem informasi yang memadai 
Selain tidak memiliki laporan keuangan yang memadai, Perusahaan juga tidak memiliki system informasi yang cukup untuk mengatur arus informasi dan data di dalam Perusahaan. Hal itu tampak dari bukti transaksi yang tumpang tindih; 1) dokumen barang masuk juga digunakan untuk dokumen barang keluar, 2) bukti kas masuk dan bukti kas keluar tidak ada, 3) tidak ada otorisasi pengeluaran kas, pemasukan kas, pengeluaran barang dan barang masuk, 4) tidak ada kebijakan tentang jumlah minimum pekerja yang hadir untuk memenuhi target produksi.

c. Dampak dari kedua hal di atas

Sebagai akibat dari kedua hal yang telah disebutkan di atas maka berdampak pada Perusahaan. Dengan target harga senilai Rp. 1.300/ kilogram yang harus dijual kepada Pelanggan tetapnya, dengan ketiadaan informasi tentang posisi keuangan Perusahaan dalam operasional bisnisnya, apakah harga jual senilai RP. 1.300/ kilogram mampu memenuhi kebutuhan aktivitas bisniss Perusahaan? Dan pada tingkat produktivitas ini apakah nilai itu reasonable untuk dapat dicapai dalam kegiatan produksi?. Perusahaan belum memiliki pedoman pencatatan yang konstruktif, sehingga aktivitas Perusahaan memiliki riwayat yang jelas bagi Perusahaan.

Berdasarlam ulasan informasi yang dipahami oleh penulis melalui pengolahan data dan kompilasi, didapatkan beberapa temuan sebagai berikut;

1. Produktivitas pabrik jauh Break Event Point yang diharapkan.

2. Terlalu banyak waktu terbuang untuk aktivitas yang tidak bernilai tambah, seperti;
a.. Proses Loading Curah
b. Setting Conveyor dan maintainance yang lama dan sering
c. Stock Opname
d. Membuat triplek
e. Muat bahan baku
f. Menata gudang dan Menyapu gudang
g. Beli bahan bakar untuk forklift

Beberapa aktivitas di atas merupakan daftar aktivitas yang sering muncul dalam kertas kerja produksi. Sebagai pabrik yang mempunyai kebutuhan 
produktivitas yang tinggi, segala aktivitas sekunder yang ada di dalam pabrik seharusnya tidak mengganggu produksi

\section{Pemakaian bahan baku yang tidak terukur}

\section{2. Menentukan Rencana}

Sistem Informasi Manajemen merupakan penerapan sistem teknologi informasi dan komunikasi pada organisasi bisnis (Kristianto et al, 2015). Rustiyanto (2011) menjelaskan sebuah sistem mempuyai ciri; alat untuk mendapatkan tujuan, sebuah kesatuan usaha, memiliki unsur fungsional (input, process, output, dan feed back), saling berhubungan, berstruktur, dan berjenjang. Implementasi sebuah sistem informasi manajemen memerlukan pendekatan yang khusus dalam tiap Perusahaan, hal tersebut memerlukan prioritas dalam membuat pilihan untuk pengembangan sistem. Voronkova (2017), O'Brien dan Marakas (2008), dan Kristianto et al (2015) memberikan tiga pendekatan utama pada pengembangan strategis sebuah sistem; target yang ingin dicapai entitas, sistem kerja yang berjalan, dan pendekatan yang situasional.

Untuk proses implementasi system informasi tersebut, hal perama yang harus dikerjakan adalah membuat rencana atas keseluruhan aktivitas utama pada Perusahaan. Berikut merupakan gambaran rencana kerja, prosedur dan arus kegitan yang akan diimplementaskan pada Perusahaan;

a. Membuat Prosedur Kerja dan Sistem Informasi Manajemen

Berdasarkan pada temuan tersebut di atas, maka aktivitas Perusahaan dapat dibagi menjadi beberapa bagian yaitu; 1) Pengeluaran Kas, 2) Penerimaan Kas, 3) Penerimaan Barang, 4) Pengeluaran Barang, dan 5) Produksi. Dari kelima aktivitas utama tersebut maka di sini Peneliti mencoba menyusun prosedur kerja sekaligus arus informasi manajemen yang dapat dikerjakan oleh Perusahaan untuk dapat menghasilkan informasi yang tepat bagi rencana strategis manajemen, berikut merupakan rencana kerja yang disusun oleh penulis;

\section{$\underline{\text { Prosedur Dana Kas Kecil }}$}

Mengingat pemegang uang (Manajer Keuangan) berada di tempat yang terpisah dengan Perusahaan, sehingga pengeluaran uang untuk aktivitas operasional seperti perawatan mesin, perbaikan gedung, pembelian ATK dan lain sebagainya 
menjadi kendala yang cukup mengganggu efektifitas kinerja Manajemen. Oleh karenanya di sini kami menyarankan untuk adanya kebijakan Kas Kecil di Pabrik, untuk mempermudah aktivitas operasional sehari-hari.

Kas Kecil secara definitif dijelaskan sebagai Kas yang digunakan untuk operasional harian Perusahaan. Adanya Kas Kecil berfungsi sebagai pembantu bagi manajemen supaya tidak disibukkan dengan aktivitas rutin semata, sehingga bisa lebih berfokus kepada penegmbangan bisnis Perusahaan. Adapun penganggungjawab dana Kas Kecil diserahkan kepada petugas yang memegang atau berwenang terhadap kegiatan di dalam Perusahaan dalam hal ini dapat sierahkan kepada Manajer Operasional. Adapun pembentukan dana Kas Kecil pada Perusahaan prosedurnya adalah sebagai berikut:

1. Manajer Keuangan menerima pengajuan dana Kas Kecil dari Manajer Operasional

2. Manajer Keuangan membuat Bukti Kas Keluar yang harus diisi dan ditandatangani olehnya.

3. Bukti Kas Keluar disampaikan ke Admin untuk dicatat dan diarsip. Adapun pencatatannya adalah sebagai berikut

Kas Kecil - Nama Pemegang \& No Bukti Kas Rp. Xxx

Kas Besar

Rp. Xxx

4. Manajer Keuangan mentransfer uang sejumlah yang telah disebutkan pada Bukti Kas Keluar kepada Penanggung Jawab di Pabrik (Manajer Operasional)

5. Manajer Operasional menerima uang dari Manajer Keuangan, Manajer Operasional membuat Bukti Kas Masuk yang disampaikan kepada Admin untuk diarsipkan. Dalam hal ini tidak ada pencatatan.

6. Setiap penggunaan dana Kas Kecil oleh Manajer Operasional harus disertai bukti transaksi yang akan dipertanggungjawabkannya kepada Manajer Keuangan di akhir periode.

7. Manajer Operasional wajib menyetor bukti-bukti transaksi hasil dari kegiatan yang menggunakan dana Kas Kecilnya yang disetor ke Admin.

8. Admin merekap total bukti transaksi yang disetor oleh Manajer Operasional dan direkoonsiliasikan dengan Bukti Kas Keluar yang diterimanya di awal. Jika selisih maka harus dapat dijelaskan oleh 
Manajer Operasional, dalam hal ini jika Manajer Operasional tidak dapat bertanggung jawab maka Admin dapat melapor ke Manajemen Keuangan guna meminta pertanggungjawaban selisih dari anggaran Kas Kecil dan realisasi transaksinya.

9. Pengajuan dana Kas Kecil hanya boleh dilakukan satu kali dalam satu periode, adapun jika ada pengajuan dana Kas Kecil lagi maka Manajer Operasional harus menyelesaikan dana Kas Kecil yang diterimanya di awal. Periode dana Kas Kecil adalah satu bulan.

10. Pengguanaan dana Kas Kecil hanya digunakan untuk aktivitas operasional pabrik, bukan untuk pengadaan barang, seperti bahan baku, mesin, peralatan kantor, atau renovasi gedung. Seluruh aktivitas tersebut dalam otoritas Manajer Keuangan. Adapun aktivitas Pabrik yang dimaksudkan adalah;

a. Perawatan mesin sekaligus pembelian suku cadang

b. Pembelian bahan bakar

c. Pembelian logistik

d. Pembayaran internet

e. Pembelian alat tulis kantor

f. Perbaikan gedung

g. Pembelian Persediaan Barang Pakai Habis, seperti oli dan grease

h. Besarnya dana Kas Kecil ditetapkan sebesar Rp. 10.000.000,sampai Rp. 15.000.000 hal ini didasarkan pengeluaran rata-rata Pabrik untuk aktivitas operasionalnya selama satu bulan. 


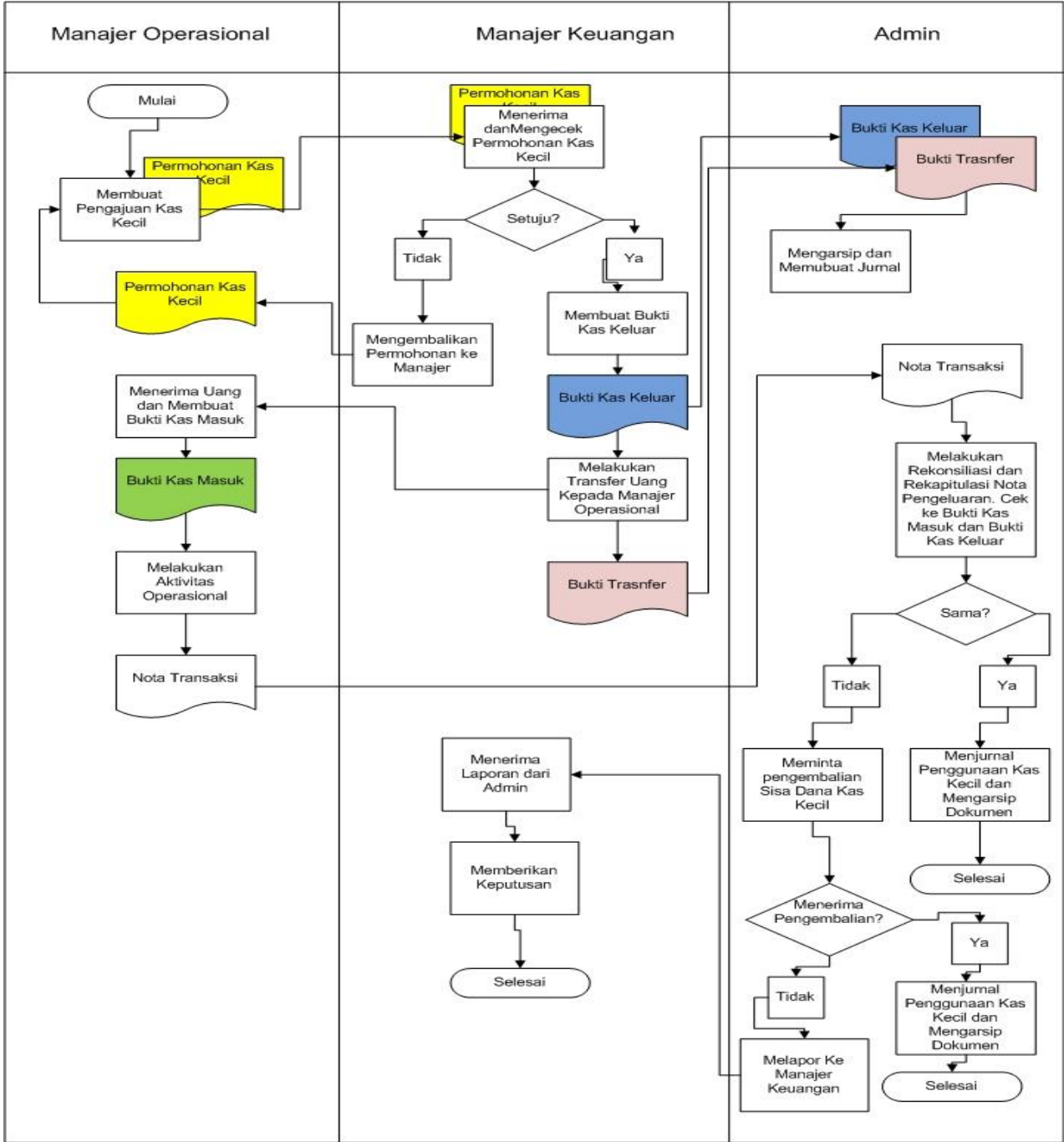

Gambar. 1. Flowchart Pengeluaran Dana Kas Kecil PT Bunga Mekar Industri

\section{Prosedur Pengadaan Barang dan Modal}

Aktivitas Perusahaan berkaitan dengan pengeluaran Kas terbagi menjadi dua; 1) Aktivitas Operasional; 2) Pengadaan Barang dan Modal. Dalam pengadaan barang dan modal, volume dan frekuensi transaksi lebih besar dari aktivitas operasional, berbeda dengan aktivitas operasional yang sifatnya taktis dan jangka pendek secara umum pengadaan barang dan modal bersifat strategis dan jangka panjang, berkaitan dengan kelangsungan hidup juga brand image yang dibangun oleh Perusahaan.. Adapun yang dapat dikatogorikan ke dalam Pengadaan Barang dan Modal ini adalah; 

a. Renovasi Gedung
b. Pembelian forklift, Kendaraan, atau ATV
c. Pembelian Bahan Baku
d. Pembelian Mesin Baru
e. Pembelian Tanah
f. Pembelian Perlatan Kantor dan Furnitur

Berdasarkan hal tersebut di atas maka prosedur pengeluaran kas untuk pengadaan barang dan modal dibedakan dengan aktivitas Operasional, berikut prosedur dan kebijakan yang diharapkan dipenuhi oleh segenap tim kerja;

1. Manajer Keuangan membuat Purchasing Order, yang harus diketahui dan disetujui oleh Direktur Utama. Purchasing Order ini berisi keterangan vendor, jumlah barang, harga barang, kualitas atau spesifikasi yang diharapkan.

2. Purchasing Order diotorisasi oleh Direktur Utama

3. Purchasing Order diketahui dan diterima oleh Manajer Operasional

4. Manajer Keuangan melakukan pemesanan barang kepada vendor, pemesanan barang juga dapat diwakilkan kepada Manajer Operasional

5. Barang dikirm oleh vendor kepada Perusahaan.

6. Barang diterima oleh Manajer Operasional dan dicek, apabila memenuhi spesifikasi maka Manajer Operasional menginformasikan kepada Manajer Keuangan bahwa barang sudah sesuai.

7. Manajer Operasional Membuat Bukti Barang Masuk, rangkap 3; 1. Untuk Admin, 2 Untuk Gudang, 3 untuk pengirim barang sebagai tanda terima.

8. Manajer Keuangan membuat Bukti Kas Keluar lalu melakukan transfer uang kepada vendor, bukti transfer dan Bukti Kas Keluar diberikan kepada Admin untuk disimpan dan dicatat. Admin mengarsip Bukti Transfer dan Bukti Kas Keluar, juga menjurnal;

Bahan Baku/ Gedung/ Peralatan/ Mesin Rp. xxx

Kas

Rp. Xxx 
9. Apabila barang yang diterima oleh Manajer Operasional tidak memenuhi spesifikasi maka Manajer Operasional melapor kepada Manajer Keuangan atau Direktur Utama untuk mendapatkan kebijakan selanjutnya.

Gambar. 2. Flowchart Pengadaan Barang PT Bunga Mekar Industri

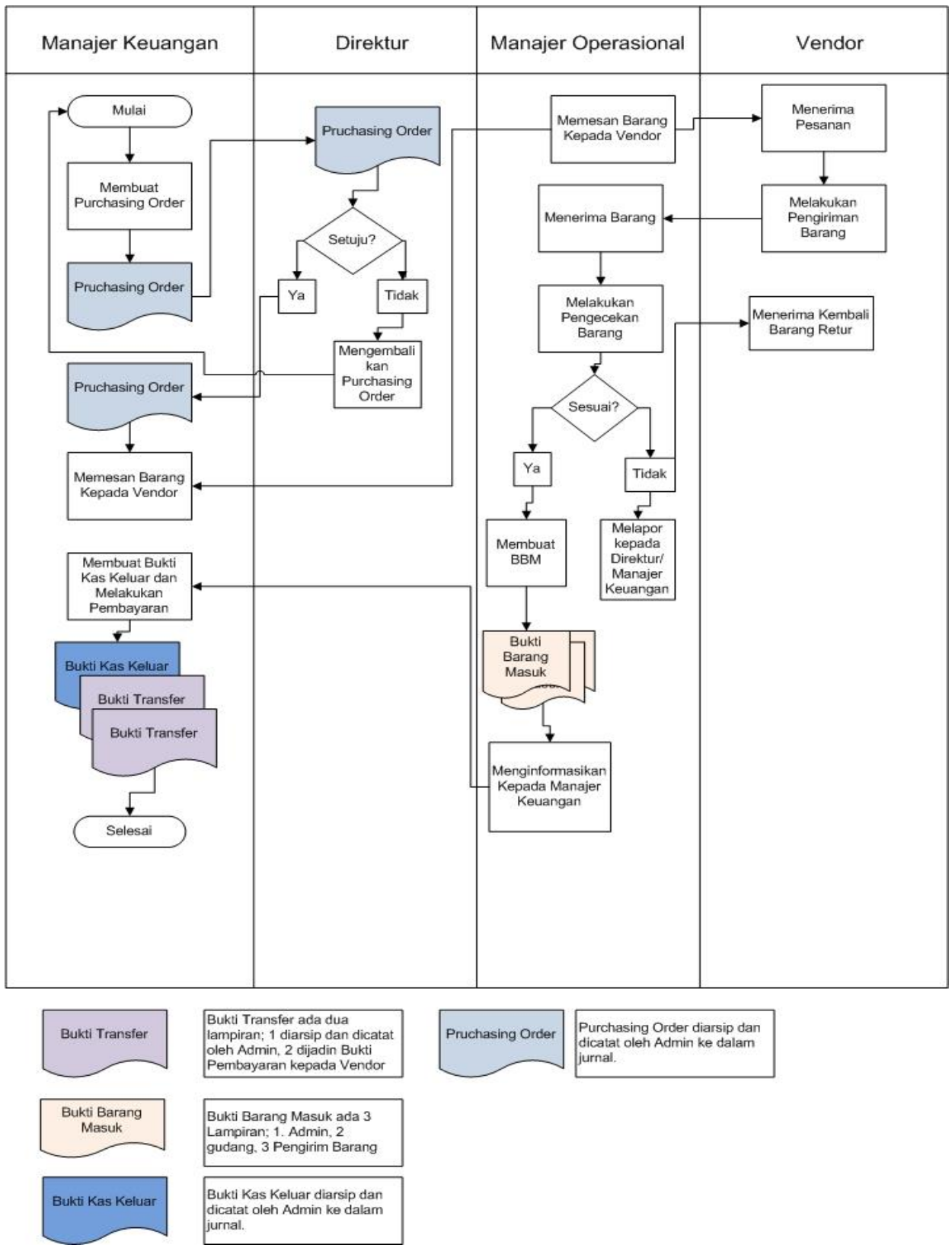




\section{Kebijakan Aktivitas Produksi}

Sebagai sebuah Perusahaan manufaktur, kegiatan utama PT Bunga Mekar Industri adalah melakukan produksi. Masalahnua, kegiatan produksi seringkali terganggu oleh aktivitas kurang bermanfaat yang pda akhirnya mengganggu efektivitas kerja dan tidak tercapainya target produksi, oleh karenanya perlu kebijakan yang baku untuk mengelola hal ini. Adapun aktivitas , b) tidak bernilai tambah yang dimaksudkan adalah; a) Proses Loading Curah, b) Setting Conveyor dan maintainance yang lama dan sering, c) Stock Opname, d) Membuat triplek, e) Muat bahan baku, f) Menata gudang dan Menyapu gudang, g) Beli bahan bakar untuk forklift.

Untuk menghindari hal serupa terjadi maka Perusahaan perlu memiliki kebijakan terkait aktivitas yang mendasar ini. Berikut keijakan Aktivitas Produksi yang harus dipatuhi oleh segenap tim produksi.

1. Manajer Operasional harus memiliki target Produksi bulanan yang akan dicapai dalam satuan waktu jam untuk produksi harian. Adapun target produksi bulanan dihitung berdasarkan cash flow Perusahaan, Kapasitas Maksimal mesin Produksi, dan target laba manajemen.

2. Dalam rangka untuk mencapai target produksi yang optimum, maka diharapkan tidak ada jam mesin yang terbuang cuma-cuma oleh tim produksi dengan aktivitas yang kurang bernilai tambah bagi Perusahaan. Selama jam kerja maka mesih harus diupayakan untuk tetap menyala dan tetap memproduksi, kecuali ada aktivitas force majeur sehingga produksi harus berhenti, seperti kerusakan parah atau perbaikan besar.

3. Dalam rangka untuk mencapai target produksi yang optimum, maka tim di bagian Produksi harus siap untuk mengawal kinerja mesin, tidak diperkenankan untuk melakukan aktivitas kerja yang lain; seperti menyapu gudang, beli bahan bakar, membuat tutup triplek dan lain sabagainya. Kegiatan semacam itu harus dserahkan kepada tim lain.

4. Dalam rangka untuk mencapai target produksi yang optimum, maka jumlah tim yang hadir untuk Produksi tidak boleh berkurang. Adapun kalau ada anggota tim yang izin maka harus dicarikan pengganti.

5. Dalam rangka untuk mencapai target produksi yang optimum, maka kegiatan yang sifatnya sekunder seperti disebutkan di atas harus dibentuk jadwal rutin, supaya tidak mengganggu aktivitas Produksi dan diupayak komitmennya supaya dalam pelaksanaannya tidak menggganggu Produksi. 
6. Dalam rangka untuk mencapai target produksi yang optimum, diupayakan supaya tim produksi telah memiliki anggaran belanja dan rencana kerja sebelumnya, sehingga aktivitas Produksi kedepan tidak terganggu dengan kegiatan sekunder yang tidak bernilai tambah.

Demikian kebijakan Aktivitas Produksi Perusahaan bagi segenap tim Produksi, harap kebijakan dini dijadikan komitmen bagi seluruh anggota tim produksi, supaya kegiatan kerja dapat berlangsung dengan baik. Selanjutnya akan diatur mengenai Prosedur Pengeluaran dan Penerimaan Barang

\section{Prosedur Penerimaan Barang non Bahan Baku}

1. Barang masuk ke PT Bunga Mekar Industri dicek oleh Admin dengan dasar Purchasing Order, Surat Perintah Kerja, atau Nota Pembelian

2. Apabila telah memenuhi kriteria maka dibuatkan Bukti Barang Masuk, bukti tersebut rangkap dua; 1 diarsip oleh Admin, 2. Diarsip oleh gudang atau departemen lain yang menggunakan barang

3. Barang kemudian dibawa ke gudang atau departemen lain yang memerlukan

4. Admin mencatat Bukti Barang Masuknya ke dalam rekapitulasi barang masuk

5. Apabila barang yang masuk tidak sesuai kriteria maka Admin dapat menghubungi Manajer Operasional/ Keungan untuk meminta kebijakan lebih lanjut.

\section{$\underline{\text { Prosedur Penerimaan Barang Bahan Baku }}$}

1. Barang masuk ke PT Bunga Mekar Industri ditimbang terlebih dahulu

2. Dicek kadar airnya dan spesifikasi lainnya sebagaimana tercantum dalam Purchasing Order

3. Jika sesuai maka Admin mencetak Bukti Barang Masuk, bukti tersebut rangkap dua; 1 diarsip oleh Admin, 2. Diarsip oleh gudang

4. Barang diterima oleh gudang

5. Bukti Barang Masuk di rekap oleh Admin

6. Apabila barang yang masuk tidak sesuai kriteria maka Admin dapat menghubungi Manajer Operasional/ Keungan untuk meminta kebijakan lebih lanjut. 


\section{Prosedur Pengeluaran Persediaan Barang Jadi}

1. Invoice telah diterima oleh Admin/ Manajer Operasional

2. Admin membuat Bukti Barang Keluar

3. Admin/ Manajer Operasonal meminta bagian gudang untuk mengeluarkan barang sejumlah Invoice

4. Barang yang dikeluarkan oleh gudang diinspeksi/ ditimbang terlebih dahulu diketahui oleh Manajer Operasional

5. Salinan Invoice, Salinan Bukti Barang Keluar diotorisasi oleh Manajer Operasional

6. Salinan Invoice, Salinan Bukti Barang Keluar diberikan kepada supir, sedangkan yang yang Asli direkap dan darsip oleh Admin

\section{Prosedur Pengeluaran Persediaan non Barang Jadi}

1. Admin menerima Permintaan Pengeluaran barang dari Departemen Lain (Dapat berupa Form PPIC atau form lain yang telah mendapat otorisasi )

2. Admin membuat Bukti Barang Keluar, lampiran 1 untuk Admin, Lampiran 2 untuk petugas yang mengajukan permintaan barang untuk dapat diarsip oleh bagian gudang

3. Form lampiran 2 Bukti Barang Keluar diberikan kepada bagian gudang untuk diarsip

4. Barang dikeluarkan oleh bagian gudang.

5. Admin merekap Bukti Barang Keluar dan mengarsipnya.

\section{Prosedur Penerimaan Kas}

\section{Penerimaan Pengembalian Dana Kas Kecil}

1. Admin menerima nota dari pengguna Kas Kecil

2. Admin melakukan rekonsiliasi atas nota yang diterima dengan Dana Kas Kecil yang telah dikeluarkan 
3. Apabila ada selisih lebih dari Dana Kas Kecil dan Nota maka pengguna Dana Kas Kecil harus mengembalikan sisanya

4. Penerimaan pengembalian ini oleh Admin dibuatkan Form Bukti Kas Masuk yang kemudian di informasikan kepada Manajer Keuangan

5. Manajer Keuangan memutuskan Kelebihan Uang Dana Kas Kecil itu dikembalikan sebagai Dana Kas Kecil periode berikutnya atau ditransfer ke rekening Perusahaan kembali

6. Form Bukti Kas Masuk diarsip dan dicatat oleh Admin

\section{Penerimaan dari Penjualan}

1. Manajer Keuangan/ Direktur Utama menerima uang masuk dari Pelanggan

2. Manajer Keuangan/ Direktur Utama menginformasikan kepada Admin dengan lampiran berupa mutasi rekening uang masuk

3. Admin membuat Bukti Kas Masuk lalu merekapnya,

4. Jumlah uang diterima harus sama dengan mutasi rekening dan penjualan

5. Admin mengarsip Bukti Kas Masuk dan salian mutasi rekening

\section{3. Melakukan Tindakan}

\section{Implementasi Sistem}

Sistem Informasi Manajemen yang telah dibuat, diaplikasikan ke dalam operasional Perusahaan. Hal tersebut dilakukan sepanjang Januari 2020 - Maret 2020. Beberapa catatan penting tentang operasional bisnis Perusahaan ditemukan dalam pelaksanaan impelemtasi system ini, beberapa diantaranya adalah;

\section{Produktivitas}

Break event point (titik impas) adalah nilai minimum yang mana suatu produk itu dijual, baik secara value maupun kuantitias berdasarkan biaya produksi tertentu. Adapun biaya produksi yang dimaksud terdiri atas; Bahan Baku Langsuns dan Pembantu + Tenaga Kerja Langsung + Overhead (Biaya Pembantu seperti listrik dan beban pabrik lainnya). Secara sederhana untuk menentukan Break event point yang perlu dilakukan hanyalah tinggal membagi antara Biaya Produksi dengan Target Harga Jual (untuk menentukan Break event point Kuantitas), sebaliknya untuk menentukan Break event point pada harga maka tinggal membagi harga jual dengan kuantitasnya. 
Selama periode 2019 - Januari 2020 didapatkan bahwa biaya produksi yang dikeluarkan oleh PT Bunga Mekar Industri adalah sebesar Rp. 250.000.000,-. Pada skala produksi sebesar itu output yang dikeluarkan oleh PT Bunga Mekar Industri sejumlah 150 jumbo bag, yang mana per jumbo bagnya berisi 800 kilogram barang jadi atau setara dengan 120.000 kilogram. Seluruh biaya produksi apabila dibagikan dengan total output maka nilainya adalah Rp. 2.083,-/ kilogram, dengan demikian apabila harga jual adalah sebesar Rp. 1.300,-/ kilogram, maka sebenarnya untuk biaya produksi saja penerimaan uang dari penjualan oleh Perusahaan tidak akan mencukupi!. Ada kerugian sebesar Rp. 783/ kilogram.

Jika penjualan bahkan tidak mencukupi untuk biaya produksi lantas apa yang salah? Apakah harga jual?. Harga jual untuk pasar ekspor produk Perusahaan adalah senilai Rp. 900,- sampai Rp. 1.400/ kilogram, dengan demikian maka sebenarnya ketika Perusahaan telah menjual pada harga Rp. 1.300/ kilogram maka sebenarnya Perusahaan telah menjual pada harga yang optimal? Lalu apa penyebabnya?. Melihat aktivitas produksi yang rendah pada table di bawah maka dapat dipahami bahwa Perusahaan harus menanggung kerugian, sebab dengan biaya produksi sebesar Rp. 250.000.000 dan pada harga jual Rp. 1.300,- maka setidaknya Perusahaan harus mempunyai output sebesar 208.000 kilogram

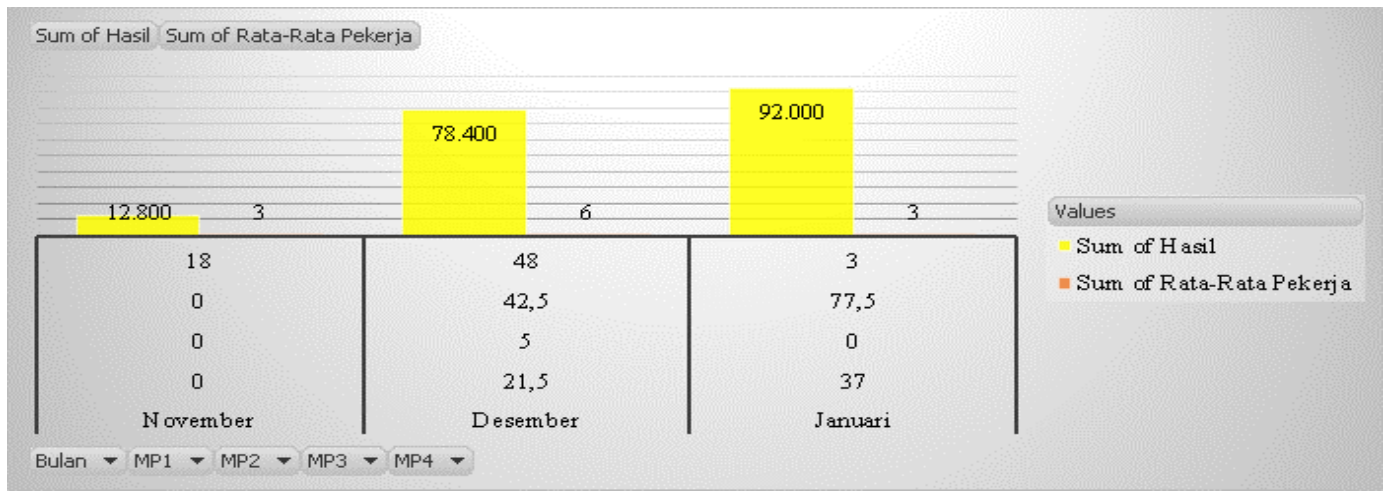

Sumber: Hasil olah data penulis

\section{Gambar. 3. Produktivitas}

Selama bulan November 2019 - Januari 2020 pabrik mulai beroperasi, tampak bahwa jam kerja mesin beroperasi secara tidak efektif sama sekali, dengan jam kerja 2 shift (16 jam) per hari rata-rata atau sebesar 80 jam per minggu atau 320 jam per bulan, jam kerja mesin hanya beroperasi pada kisaran 18 - 77 jam per bulan dengan kondisi akt ivitas yang tidak seimbang, artinya keempat mesin produksi tidak dapat bekerja secara efektif dan simultan selama jam kerja tersebut, yang mana artinya ketika salah satu mesin bekerja maka mesin yang lain dapat dipastikan 
mati atau kalaupun dapat bekerja secara simultan maka mesin tidak akan mampu bekerja dalam durasi yang sama secara bersama-sama.

Target produksi untuk mencapai BEP sebesar 208.000 kilogram tersebut bukanlah hal yang berat selama manajemen mampu berkomitmen untuk mencapainya. 208.000 kilogram per bulan artinya 8.333 per hari atau 521 per jam, yang mana jika Perusahaan memiliki 4 mesin produksi maka Perusahaan semestinya mampu memproduksi sebesar 130 kilogram per jam per mesin produksi!, hanya untuk mencapai BEP dalam satu bulan.

\section{Tabel 1. Simulasi Produksi}

\begin{tabular}{l|r|r|r|r|r|r|}
\hline Bulan & \multicolumn{1}{|c|}{ Hasil } & \multicolumn{1}{|c|}{ MP1 } & \multicolumn{1}{c|}{ MP2 } & \multicolumn{1}{c|}{ MP3 } & MP4 & Rata-Rata Pekerja \\
\hline November & 208.332 & 320 & 320 & 320 & 320 & 8 \\
\hline Desember & 208.332 & 320 & 320 & 320 & 320 & 8 \\
\hline Januari & 208.332 & 320 & 320 & 320 & 320 & 8 \\
\hline
\end{tabular}

Sumber: Hasil olah data penulis

Tabel 2. Target Produktifitas Mesin

\begin{tabular}{|c|c|c|c|}
\hline Mesin & Jam Produksi Harian & Target Harian & Penyelesaian \\
\hline MP1 & 16 & 130 kilogram & jam \\
\hline MP2 & 16 & 130 kilogram & jam \\
\hline MP3 & 16 & 130 kilogram & jam \\
\hline MP4 & 16 & 130 kilogram & jam \\
\hline
\end{tabular}

Sumber: Hasil olah data penulis

Produktivitas mesin yang rendah juga didukung oleh rendahnya tingkat produktivitas tenaga kerjanya. Tenaga kerja juga menjadi isu yang penting bagi Perusahaan, ketiadaan tenaga kerja artinya tidak adanya sumber daya yang memproses bahan baku di dalam pabrik, tercatat selama periode November 2019 Januari 2020 rata-rata kehadiran per bulan adalah 3 - 6 orang, sementara kebutuhan pabrik untuk dapat menjalankan mesin agar dapat memproduksi secara optimal adalah 8 orang. Rendahnya tingkat produktivitas tenaga kerja sangat mempengaruhi 
proses produksi pabrik, ketergantungan mesin akan tenaga kerja pengolahnya menjadi sangat besar apabila Pabrik ingin produksi dapat tercapai secara optimal.

Untuk dapat mencapai BEP maka mesin harus bekerja secara optimal ditunjang dengan kehadiran tenaga kerja yang mendukung hal itu. Berikut table perbandingan kondisi actual dan yang diharapkan.

\section{Aktivitas tak bernilai tambah}

Selain kinerja mesin yang tidak efektif dan ketidakhadiran tenaga kerja selama jam kerja, rendahnya tingkat produktivitas pabrik juga didukung dengan banyaknya aktivitas yang tidak bernilai tambah selama jam kerja. Jam kerja yang semestinya dipakai untuk menghasilkan produk jadi pada kenyataannya habis untuk aktivitas yang lain

\section{Penggunaan bahan baku yang tidak terukur}

Pemakaian dan pembelian bahan baku yang tidak terdokumentasikan dengan baik dan terencana dengan baik menjadikan pembebanan persediaan kepada biaya produksi menjadi tidak dapat diketahui dengan baik, pencatatan pada catatatn kegiatan produksi yang bersifat perkiraan menjadikan informasi yang diperoleh kurang informative.

Setiap barang masuk dan datang harus dibuatkan catatan terpisah dengan dokumen pendukung yang berbeda sehingga riwayat keluar masuknya barang dapat diketahui dengan baik dan kinerja dapat dipertanggungjawabkan kepada manajemen. Apa yang dilakukan oleh produksi saat ini adalah mencatat barnag keluar tidak pada nilai terpakainya tapi dalam perkiraan nilai tersisa.

Tidak tercatatnya pemakaian barang dengan baik menyebabkan perhitunga biaya produksi menjadi tidak akurat, yang akan berimbas pada tingkat laba yang diharapkan dan tingkat produktivitas optimum Perusahaan. Sebagai contoh pada bulan Januari 2020, yang mana estimasi bahan baku terpakai adalah $60 \%$ dari bahan baku tersedia di bulan itu atau sejumlah Rp. 176.000.000 dan 467.241 kilogram dalam satuan kuantitasnya, namun penyerapannya untuk barang jadi hanya sebesar 92.000 kilogram, terjadi pemborosan yang luar biasa besar mengingat dari catatan yang diperoleh dari pihak manajemen, residu bahan baku dari aktivitas produksi kurang dari $1 \%$, namun output produksi dibandingkan dengan pemakaian bahan baku sangat jauh sekali, tercatat hanya $20 \%$ dari total bahan baku yang dipakai yang menjadi output barang jadi, sisanya kemana?. Sekalipun Perusahaan telah memiliki tingkat penjualan yang baik di sepanjang Januari 2020, yang mana telah menjual 
99,5\% hasil produksi November 2019 - Januari 2020 namun Perusahaan masih menyisakan hal penting, yaitu pemakaian bahan baku yang tidak terukur.

\section{4. Dampak Implementasi Sistem}

Setelah system kerja disusun dan diintegrasikan ke dalam Perusahaan, maka dari aktivitas tersebut Perusahaan memiliki catatan yang memadai dan data hasil kerja yang akurat, sehingga manajemen dapat melakukan evaluasi dan perbaikan yang menyeluruh terhadap aktivitas bisnisnya. Sebagai dampak dari informasi manajemen yang memadai dan perbaikan yang menyeluruh, didapati data sebagai berikut dibawah;

Berdasarkan informasi tersebut di atas, dapat dipahami bahwa Perusahaan telah mencapai perubahan yang radikal pada operasional bisnisnya, mengawali tahun 2020 dengan kerugian mencapai Rp. 135.520.155,- Perusahaan telah memperbaiki system kerja manajemen hingga pada akhir Maret 2020 membukukan keuntungan kotor senilai Rp. 6.637.716,--.

Meskipun level pemakaian bahan baku belum dapat ditelusur secara akurat, estimasi pemakaian bahan baku telah dapat menggambarkan berapa banyak komposisi biaya bahan baku di dalam biaya manufaktur.

\section{5. Pembelajaran}

Bisnis yang professional membutuhkan tanggungjawab dan komitmen yang sungguh-sungguh pada setiap bagian pada manajemen, maka untuk menjaga profesionalitas kerja dan tanggungjawab tersebut setiap aktivitas di dalam organisasi harus tercatat, selain sebagai fungsi control hal tersebut juga merupakan bagian dari alat ukur kinerja bagi Perusahaan yang dengannya maka Perusahaan dapat menilai dan membuat capaian strategis di masa yang akan datang.

Hasil dari implementasi sistem informasi manahemen menunjukkan bahwa segala catatan aktivitas Perusahaan memberikan informasi untuk dapat melakukan perubahan juga perbaikan bagi Perusahaan. Perusahaan dapat meningkatkan profitabilitasnya berawal dari kerugian bernilai ratusan juta rupiah menjadi untung dalam hitungan bulan, pada tahun yang sama.

\section{Kesimpulan}

Penelitian dengan pendekatan action research ini menghasilkan kesimpulan bahwa PT Bunga Mekar Industri mengalami kerugian disebabkan oleh tidak efektifnya jam kerja mesin dan tim produksinya, penggunaan bahan baku yang tidak terukur, dan seringnya tim produksi absen menjadi persoalan. Pada saat yang sama PT Bunga Mekar Industri tidak memiliki arus dokumen yang memadai untuk 
mencatat semua aktivitas itu. Hasil dari action research dalam penelitian ini; 1) Membuat dokumen barang masuk, kas masuk, barang keluar, kas keluar; 2) membuat prosedur untuk semua aktivitas Perusahaan, meliputi keuangan, persediaan, pengadaan, dan produksi; 3) membuat kebijakan produksi dan penghitungan biaya produksi untuk dapat menghadirkan laporan produktifitas kepada manajemen.

\section{Keterbatasan}

Penelitian berbasis pada action research merupakan penelitian yang spesifik, artinya baik hasil maupun metodenya tidak dapat digenelaisir dan direplikasi pada kasus lain, sekalipun memiliki persoalan yang sama, sebab kondisi setiap organisasi dan subjek Penelitian selalu berbeda antara satu dan lainnya. 


\section{Daftar Pustaka}

Coghlan, David. Brannick, Teresa. (2005). Doing Action Research In Your Own Organization. $2^{\text {nd }}$ Edition. $\quad$ Sage Publication.

Farhan, Ali. (2017). Menyusun Nisbah Bagi Hasil Pembiayaan Mudharabah Untuk Usaha Mikro Pada BMT UGT Sidogiri. Thesis. Airlangga University.

Greenwood, D., M.B. Miler, dan P. Maguire. (2003). Why Action Research. SAGE Publications: London

Huda, Nurul. Sawarjuwno, Tjiptohadi. (2013). Akuntabilitas Pengelolaan Zakat Melalui Pendekatan Modifikasi Action Research. Jurnal Akuntansi Multiparadigma Vol. 4, No. 3.

Kong, N., Fosmire, M., \& Branch, B. D. (2017). Developing library GIS services for humanities and social science: An action research approach. College \& Research Libraries, vol 78, no.4: 413-427.

Korb, D. S., \& Wagner, S. L. (2016). The Finicky Grape Winery Action Research in Wine Accounting. In 9th Academy of Wine Business Research Conference (p. 86).

Kristianto, Wheny. Supriyanto, Totok. Wahyuni, Sri. (2015). Sistem Informasi Manajemen (Pendekatan Sosioteknik). UPT Penerbitan Unej. Jember. ISBN: 978-602-9030-96-9 .

O’Brien, J.A dan Marakas, G.M. (2008). Introduction to Information Systems. McGraw-Hill/Irwin.

Rustiyanto, E. (2011). Sistem Informasi Manajemen, Edisi Revisi. Gosyen Publising, Yogyakarta.

TRIPP, David. (2005). Action research: a methodological introduction. Educacao epesquisa, Vol 31, no.3: 443-466.

Voronkova, O.V. Aleksandrovna, Anna. (2017). Implementation of an information management system. for industrial enterprise resource planning. Espacios. Vol. 39. 2017.

Wageman, Andrea. Witschge, Tamara. (2019). Examining innovationas process: Action research in journalism studies. Convergence: The International Journal of Research into New Media Technologies 25(2). 